\title{
The Effects of Message Tone and Formats of CSR Messages on Engagement in Social Media
}

\author{
Myoung-Jin CHAE ${ }^{1}$
}

Received: July 25, 2020 Revised: August 23, 2020 Accepted: August 29, 2020

\begin{abstract}
As more consumers are interested in sustainability issues and evaluate brands based on their social responsibility issues involved, firms are using social media platforms in order to communicate with consumers about Corporate Social Responsibility (CSR) activities. However, the current literature focuses mostly on factors drive engagement of promotional messages, while little evidence was found in the literature on how to design effective CSR messages on social media to engage consumers. Using over 3,000 branded posts on Facebook and Twitter, this research explores factors that help CSR messages become more engaging in social media. The results show that, on average, CSR messages had a negative significant effect on consumer engagement. However, CSR messages became more engaging when designed with emotional appeals, longer texts, and a hashtag. While marginal, CSR messages with informational appeals and humor undermined the effect of CSR messages on engagement. Finally, we explore different types of CSR messages by their beneficiary scope and the role of brands in the message and discuss what message contents drive more engagement in social media. This research contributes to the academic literature and managers by providing new insights on how to design CSR messages for effective communications in social media.
\end{abstract}

Keywords: Corporate Social Responsibility, Social Media, Sustainability, Consumer Engagement, Online Content

JEL Classification Code: M14, M31, M37, Q01, M10

\section{Introduction}

With consumers' increased interests in sustainability issues, firms need to take their Corporate Social Responsibility (CSR) activities more seriously and effectively communicate with consumers in order to improve brand image. Social media is a new communication platform where firms can have a chance to generate brand pages and post their products- or events- related contents for more effective communications with consumers in real-time. Moreover, social media provides firms opportunities to communicate about their CSR activities. CSR-related communications on social media can be categorized as having two purposes - 1) inform consumers regarding what CSR activities firms are

${ }^{1}$ First Author and Corresponding Author. Assistant Professor, Department of Marketing and International Business, Lingnan University, Hong Kong [Postal Address: 8 Castle Peak Road, Tuen Mun, Hong Kong] Email: myoungchae@In.edu.hk

(c) Copyright: The Author(s)

This is an Open Access article distributed under the terms of the Creative Commons Attribution Non-Commercial License (https://creativecommons.org/licenses/by-nc/4.0/) which permits unrestricted non-commercial use, distribution, and reproduction in any medium, provided the original work is properly cited. involved in for improvements in brand image and reputation and 2) ask for consumers' participation in their CSR activities. Indeed, brand perception is found to be influenced by firms' activities in social media. As an example, Coca Cola's PlantBottle campaign tried to make young eco-friendly minded consumers see Coca Cola's bottles differently. The campaign led to a huge success, leading half of a million views in 5 days. After the social media campaign, Coca-Cola achieved a $10 \%$ increase in positive brand perception and a $66 \%$ reduction in negative comments about the brand.

While social media platforms provide great opportunities for firms to expand CSR communications, understanding of effective CSR communications in academic literature is still at an early stage. Study findings have mostly focused on the role of social media as an effective communication platform to promote their brands or products, which will ultimately lead to purchase. More specifically, most of the studies have explored the effects of content characteristics in social media on consumer engagement (e.g., Akpinar \& Berger, 2017; De Vries, Gensler, \& Leeflang, 2012; Lee, Hosanagar, \& Nair, 2018; Stephen, Sciandra, \& Inman, 2015; Rietveld, Van Dolen, Mazloom, \& Worring, 2020; Yang, Ren, \& Adomavicius, 2019). 
Given that CSR-related messages by brands will work under different mechanisms from most of promotionrelated messages created by brands, this research explores how firms can communicate their CSR related issues more effectively and generate higher engagement in social media. First, we explore if CSR related messages drive engagement in social media in general. Second, we explore message tone and format factors that help CSR messages become more engaging. Lastly, as an additional analysis, we also explore different types of issues within CSR messages and find ways to design more effective CSR messages in social media.

\section{Literature Review and Theoretical Development}

\subsection{Corporate Social Responsibility (CSR)}

While firms are mainly involved in promotional activities, they also put efforts and resources to CSR activities, which refer to "a company's status and activities with respect to [i.e., responsiveness to] its perceived societal obligations" (Brown $\&$ Dacin, 1997). While the main purpose of such activities is to give back to the society and contribute to the community, firms also obtain benefits from such activities. It has been known that CSR activities increase consumers' positive word of mouth as well as willingness to pay a premium price and help consumers become more resilient to firms' negative news after CSR actions (e.g., Du, Bhattacharya, \& Sen, 2007). Such positive attitudinal outcomes lead to financial performance (Ali, Salman, Yaacob, Zaini, \& Abdullah, 2020; Amacha \& Dastane, 2017; Freedman \& Jaggi, 1982; Pava \& Krausz, 1996).

It has become imperative to communicate with consumers about CSR activities because they expect that firms will be involved in CSR activities and are interested in learning the types of causes supported by the firm. According to a survey in 2017,63\% of Americans say they hope that businesses would take the lead to make important social and environmental changes moving forward, regardless of government regulations. The survey results further indicate that $90 \%$ of consumers want firms to address important social justice issues. Their interests are also related to purchase decisions $-87 \%$ will purchase a product for a company advocating for an issue they care about and $76 \%$ will refuse to purchase a product for a company if they learn that it supported an issue that is contrary to their belief (Cone Communications, 2017).

\subsection{Consumer Attitude Towards CSR Activities}

Since firms claim that they are involved in CSR activities for the purpose of community rather than serving their own profit, consumers' evaluations toward such activities differ from those toward promotional activities. In the CSR literature, it has been found that consumers evaluate CSR activities as well as the brands based on perceived authenticity of such activities and become skeptical if the activities do not seem authentic (e.g., Alhouti, Johnson, \& Holloway, 2016; Mohr, Webb, \& Harris, 2001; Skarmeas $\&$ Leonidou, 2013). According to the previous studies, consumers make judgments about firms' motives of CSR activities and perceive them as authentic if such activities have others-serving (or public-serving) motives (e.g., Ellen, Webb, \& Mohr, 2006; Mohr et al. 2001). In contrast, consumers perceive such activities as inauthentic and become more skeptical if the activities seem to serve selfserving motives (i.e., serving the firm's own profit rather than a cause or others). Perceived authenticity of the CSR activities is the main driver of positive evaluations toward the activities and firm image. The effect of perceived motives of CSR activities on consumer-brand relationships was also found in recent social media research (Sreejesh, Sarkar, \& Sarkar, 2019), which implies that such mechanism could work in the social media context.

\subsection{CSR in Social Media}

While most studies in social media have focused on the effectiveness of promotional messages, of which the main purposes are promoting products or brands, understanding how CSR messages work in social media is still at an early stage. Some scholars have argued that firms need to make use of social media platform as ways to communicate CSR activities (e.g., Adi \& Gregore, 2015; Park, 2019). Recently, there are works on the effectiveness of CSR messages by types or topics (e.g., Saxton, Gómez, Ngoh, Lin, \& Dietrich, 2019; Wang \& Huang, 2018). Although social media seems to resonate with CSR messages (e.g., Saxton et al., 2019), the effects of CSR messages on engagement depend on various factors and still leave room for further exploration. This research builds on the literature and explores how to design CSR-related messages more effectively so that they drive higher engagement in social media. More specifically, drawing upon the social media and advertising literature, we explore message tone and format factors as moderators and analyze what factors help or undermine the effectiveness of CSR messages on social media.

\subsection{Consideration of Message Tone in Social Media}

A large body of the advertising literature has distinguished messages between emotional and informational appeals (e.g., Akpinar \& Berger, 2017; Chandy, Tellis, MacInnis, \& Thaivanich, 2001; MacInnis, Rao, \& Weiss, 2002). According to the literature, emotional appeals refer to 
"designed to appeal to emotions by using mood, music, and other emotion-eliciting strategies", while informational appeals are defined as "designed to appeal to cognition by using objective information describing a brand's attributes or benefits" (Akpinar \& Berger, 2017; MacInnis et al., 2002). Scholars have found that emotional messages drive positive feelings about the brand or product and therefore improve positive reactions (Goldberg \& Gorn, 1987). In addition, emotional messages are found to persuade and motivate consumers (Andrade \& Cohen, 2007) and guide to form an attitude (Bagozzi, Gopinath, \& Nyer, 1999).

Scholars have found a positive effect of emotional messages on virality (Heath, Bell, \& Strenberg, 2001; Rimé, 2009) and the evidence was also found in social media (Akpinar \& Berger, 2017; Lee et al., 2018) and online (Berger \& Milkman, 2012). While there are mixed findings regarding the underlying mechanisms, an emotional arousal improves social transmission (Berger, 2011). Also, surprising or interesting contents are shared more since it makes consumers look good (Berger \& Schwartz 2011; De Angelis, Bonezzi, Peluso, Rucker, \& Costabile, 2012; Moldovan, Goldenberg, \& Chattopadhyay 2011). In line with the findings in the literature, we also argue that making CSR messages emotional will help engagement because emotional appeals will help social transmission and increase shares because those messages make consumers look good.

While emotional messages have positive impacts on engagement in general, informational contents have mixed findings in the literature (Rietveld et al., 2020). Studies have found that informative appeals induce cognitive processing using objective information abouta brand's benefits (MacInnis et al., 2002). Some scholars argue that informational appeals have a positive effect because they provide relevant product information which reduce uncertainty associated with purchase (Rietveld et al.,2020). Also, informative messages improve consumers' understanding of unique or useful product or brand features (Yoo \& MacInnis, 2005). However, informational appeals have a negative effect because they signal that the message has a persuasion attempt, which is not consistent with consumer motivation to follow brands (Muntinga, Moorman, \& Smit 2011). In addition, they make consumers suspicious of sales motives and make consumers cope with the persuasion attempts, thereby in turn undermine the communication effectiveness (Verlegh, Verkerk, Tuk, \& Smidts, 2004). In this research context, given that the ulterior motives of CSR messages are not to promote brands or products, we predict that consumers will be more sensitive to messages' persuasion attempts and become easily skeptical. Therefore, informative appeals which attempt to help consumers' understanding might have negative consequences because they lead consumers to be suspicious of sales motives.
H1: Emotional appeals in a message will lead CSR messages to higher levels of engagement in social media.

H2: Informational appeals in a message will lead CSR messages to lower levels of engagement in social media.

\subsection{Consideration of Message Format in Social Media}

Humor is one of the common tactics used in advertising and therefore its effectiveness has been well studied in the literature. In many studies, use of humor was found to have positive impacts by inducing positive affect and improving attitude towards the advertiser (e.g., Madden \& Weinberger, 1984; Sternthal \& Craig, 1973) and purchase intentions (e.g., Madden \& Weinberger, 1984; Weinberger \& Gulas, 1992). However, studies of humor in advertising over the decades have mixed findings and many scholars have doubt on its effectiveness. A meta-analysis by Eisend (2009) also shows evidence that the impact of humor has mixed findings. Some scholars argue that humor has no impact (e.g., Weignberger \& Campbell, 1991; Woltman Elpers, Mukherjee, \& Hoyer, 2004) as it works as a distractor to understand the message regarding brand benefits. Bryant, Alan, Silberberg, and Elliott (1981) argue that humor decreases source credibility and therefore reduces persuasiveness of the ad, when discussing serious issues. Similarly, Speck (1987) found the negative relationship between level of perceived humor and source trust. In the meta-analysis by Eisend (2009), the effect of humor on source credibility was also negative.

We argue that, while depending on contexts, humor in CSR messages may have negative impacts. Given the idea that humor can decrease source credibility and be seen as the marketer's weakness when making serious arguments (Bryant et al., 1981; Eisend, 2009), use of humor in CSR messages can impair seriousness and authenticity of the motives that brands attempt to deliver in the messages. As consumers evaluate CSR messages based on its true motives and authenticity, we argue that humor can play a negative role in conveying their serious messages about others-serving motives rather than serving their own motives and profits.

H3: Humor in a message will lead CSR messages to lower levels of engagement in social media.

Next, we discuss two additional message format factors - i.e., length of text and a hashtag - which are commonly considered by social media marketers. We argue that the length of text is related to perceived efforts put in the message. Therefore, consumers will perceive that the marketers put more effort in a message for better quality in order to communicate with the consumers if the text is longer in the message. For CSR-related messages, higher levels of perceived effort will increase the perception that the 
firm has others-serving motives than self-serving motives. In turn, perceptions of others-serving motives of CSR messages will lead to perceived authenticity of CSR, which lead to more positive evaluations towards the CSR activities (Alhouti et al., 2016; Ellen et al., 2006). Similarly, messages commit to quality were positively related to authenticity in the advertising literature (Beverland, 2006; Gilmore \& Pine, 2007; Napoli, Dickinson, Beverland, \& Farrelly, 2014).

Likewise, a hashtag (i.e., short words or phrases that follow the hash or pound sign (\#), Saxton, Niyirora, Guo, $\&$ Waters, 2015) is one of the commonly used practices in social media. Hashtags are used for multiple purposes such as brand advocacy movements, receive messages for the movements, and most importantly, being exposed to likeminded people who are not personally connected (Saxton et al., 2015). Therefore, use of a hashtag is a way to make messages more viral. In addition, a hashtag in a message can provide the perception that the firm is making efforts to spread out the message and communicate with like-minded consumers. Therefore, it will lead to the perceptions of others-serving motives and thereby lead to higher perceived authenticity.

H4: Longer texts in a message will lead CSR messages to higher levels of engagement in social media.

H5: Hashtag in a message will lead CSR messages to higher levels of engagement in social media.

Overview of the theoretical framework with the above hypotheses is shown in Figure 1.

\section{Methodology}

\subsection{Data}

We chose Facebook and Twitter as the platforms for our main analysis because they are the most popular platforms with the largest number of users and brands accounts. For the analysis, 3,252 branded posts by 11 international brands on Facebook and Twitter during the period of January to December 2014 were collected. The data was collected by university students in Hong Kong for our main study variables and using text analysis tools to extract information from the posts.

\subsubsection{Dependent Variables}

As a way to measure consumer engagement, we consider the number of Likes (or Favorites on Twitter), Shares (or Retweets on Twitter), and Comments on Facebook and Twitter. Social media platforms, especially Facebook and Twitter, utilize those three main items as a way that consumers can respond to their posts. In addition, the three metrics have been commonly used by social media researchers in the past (e.g., Akpinar \& Berger, 2017; De Vries et al., 2012; Stephen et al., 2015). While we analyze Likes and Shares with the full data, only partial data was available for Comments $(n=2,193)$. Therefore, our study focuses more on Likes and Shares as main dependent variables and consider analysis of Comments as robustness checks.

\subsubsection{Independent Variables}

We collected our main study variables by asking consumers to read and review the posts using the instructions given. For the main independent variable, we collected CSR messages by asking if the posts provide information about the social good/social responsibility of the product. Likewise, Informational and Emotional messages were tagged in the same way with appropriate descriptions given to consumers. For message format characteristics, Humor was tagged by consumers and Length of Text and Hashtag were collected using text analysis.

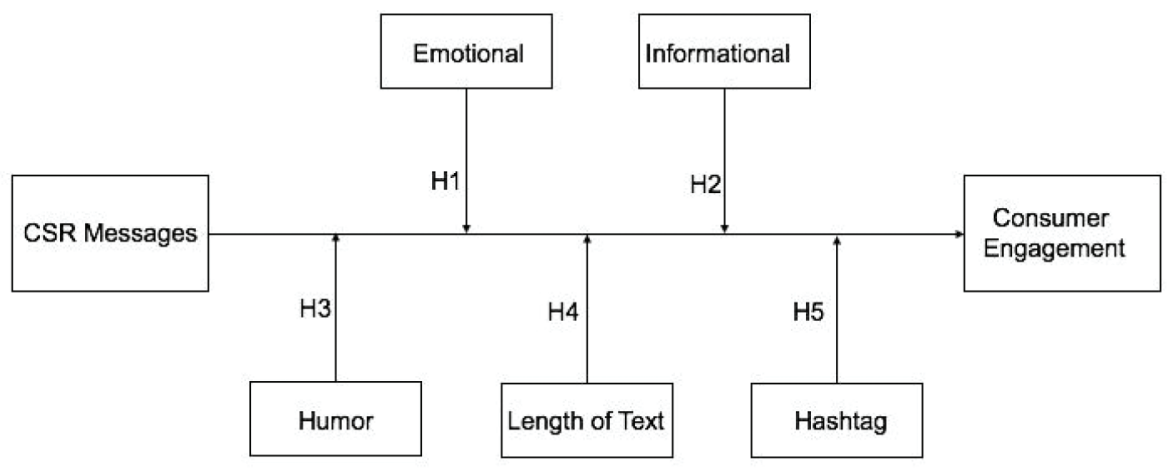

Figure 1: Proposed Theoretical Framework 


\subsubsection{Control Variables}

In order to consider other variables that affect consumer engagement in social media, we followed the steps in the previous social media studies. Scholars have found message content and format characteristics that affect engagement in social media (e.g., De Vries et al., 2012; Lee et al., 2018; Stephen et al., 2015; Yang et al., 2019). According to the literature, we considered format variables as Picture, Video, Question, URL and content variables as Monetary, People, Product, Call to Action into our model. In addition, we also considered Platform as an additional control variable in the model. More details of variable descriptions, measures, and descriptive statistics are provided in Table 1.

\subsection{Empirical Considerations}

In order to test the hypotheses, we address the following empirical considerations in order to handle issues from the nature of data. First, as our dependent variables are count variables with overdispersion, we adopt a negative binomial regression model in analysis following the previous social media studies (e.g., Yang et al., 2019). Second, it is likely that consumer engagement on the previous posts by a brand affects the engagement level on the next post. Brands adopt similar communication styles across posts and are likely to consider consumer responses to previous posts when they upload the next posts. Moreover, Facebook's Edgerank algorithm is known to select and show posts to consumers based on "Time" - i.e., engagement on a previous post affects the next post (Stephen et al., 2015). Therefore, we include lagged dependent variables in our model. Third, it is likely that how brands engage consumers in social media is different across brands as they have their organizational culture, communication styles, characteristics of fans, types of products, etc. Therefore, we include brand fixed effects in our model. Fourth, it is likely that brands release their posts considering the month and day of week and therefore we also incorporate time as additional controls in the model. Considering the above, our model equation is as below.

Table 1: Overview of the Variables and Descriptive Statistics

\begin{tabular}{|c|c|c|c|}
\hline Variable & Descriptions & Mean & SD \\
\hline Likes (Favorites) & The number of likes (or favorites) the message received & 2430.98 & 10563.78 \\
\hline Shares (Retweets) & The number of shares (or retweets) the message received & 406.05 & 2542.37 \\
\hline Comments & The number of comments the message received & 181.39 & 2651.59 \\
\hline CSR message & $\begin{array}{l}\text { The message provides information about the social good/social responsibility } \\
\text { of the product or brand* }\end{array}$ & 0.16 & 0.36 \\
\hline Emotional & $\begin{array}{l}\text { The message is using an emotional appeal to gain consumer interest or } \\
\text { attention* }\end{array}$ & 0.59 & 0.49 \\
\hline Informational & $\begin{array}{l}\text { The message is using an information-based/rational appeal to gain consumer } \\
\text { interest or attention* }\end{array}$ & 0.30 & 0.46 \\
\hline Humor & The message is using a humor* & 0.17 & 0.37 \\
\hline Length of Text & Number of characters in the message & 102.04 & 61.33 \\
\hline Hashtag & The message contains a hashtag* & 0.52 & 0.50 \\
\hline Monetary & $\begin{array}{l}\text { The message provides information about the monetary benefits of the product } \\
\text { such as reduced price or more value for money* }\end{array}$ & 0.06 & 0.23 \\
\hline Picture & The message contains a picture* & 0.73 & 0.44 \\
\hline People & The message contains images of people* & 0.40 & 0.49 \\
\hline Product & The topic of the message is about product* & 0.40 & 0.49 \\
\hline Video & The message contains a video* & 0.14 & 0.34 \\
\hline Question & The message contains a question* & 0.17 & 0.38 \\
\hline Call to Action & $\begin{array}{l}\text { The message contains calls to action (e.g., invitations to watch a video, visit a } \\
\text { website, respond to a question, etc.) }{ }^{*}\end{array}$ & 0.35 & 0.48 \\
\hline URL & The message contains a URL* & 0.36 & 0.48 \\
\hline Platform & $1=$ Twitter $/ 0$ = Facebook & 0.50 & 0.50 \\
\hline
\end{tabular}

Note: * $(1=$ Yes/ $0=$ No $)$ 


$$
\begin{aligned}
& \text { Likes }_{\mathrm{ij}}=\alpha 0+\beta 1 \mathrm{X}_{\mathrm{ij}}+\beta 2 \text { Controls }_{\mathrm{ij}}+\beta 3 \text { Brand Fixed } \\
& \text { Effects }_{\mathrm{i}}+\beta 4 \text { Time effects }_{\mathrm{ij}}+\varepsilon_{\mathrm{ij}} \\
& \text { Share }_{\mathrm{ij}}=\alpha 0+\beta 1 \mathrm{X}_{\mathrm{ij}}+\beta 2 \text { Controls }_{\mathrm{ij}}+\beta 3 \text { Brand Fixed } \\
& \text { Effects }_{\mathrm{i}}+\beta 4 \text { Time effects }_{\mathrm{ij}}+\varepsilon_{\mathrm{ij}} \\
& \text { Comments }_{\mathrm{ij}}=\alpha 0+\beta 1 \mathrm{X}_{\mathrm{ij}}+\beta 2 \text { Controls }_{\mathrm{ij}}+\beta 3 \text { Brand } \\
& \text { Fixed } \text { Effects }_{i}+\beta 4 \text { Time effects }_{i j}+\varepsilon_{i j}
\end{aligned}
$$

For brand $i$ 's $j^{\text {th }}$ post, $X_{i j}$ represents a vector of our main study variables; Controls ${ }_{\mathrm{ij}}$ denotes a vector of control variables considered in our model; Brand Fixed Effects represents brand fixed effects and Time effects ${ }_{\mathrm{ij}}$ represents month and day of week posts are released.

\section{Results}

\subsection{Main Analysis}

First, the main effect analysis shows that CSR messages had a negative and significant effect on consumer engagement across Likes $(b=-.053, p<.05)$, Shares $(b=-1.029, p<.01)$, and Comments $(b=-.743, p<.10)$ on average. The results show that branded messages containing CSR information are less engaging than non-CSR related messages. Next, we examined several message tone and format factors as moderators and tested their interaction effects with CSR messages. For the message tone factors, CSR messages became more engaging when containing emotional appeals (Likes: $\mathrm{b}=.468, \mathrm{p}<.10$; Shares: $\mathrm{b}=.521, \mathrm{p}<.05$; Comments: $\mathrm{b}=.617, \mathrm{p}<.01)$. However, when CSR messages contain informational appeals, the effects of CSR messages became more negative on Comments $(b=-1.065, p<.01)$ while the interaction effects between CSR and informational appeals were not significant on Likes $(p=>.10)$ and Shares $(\mathrm{p}=>.10)$. The results provide evidence for $\mathrm{H} 1$ and partial support for $\mathrm{H} 2$.

The effect of humor in CSR messages was only significant and negative on Shares $(b=-.491, p<.10)$ and not significant on Likes $(p=>.10)$ and Comments $(p=>.10)$, showing partial support of H3. For the remaining message format factors, the interaction effects of text length and CSR messages were positive and significant across Likes $(\mathrm{b}=.002, \mathrm{p}<.10)$, Shares $(\mathrm{b}=.004, \mathrm{p}<.01)$, and Comments $(\mathrm{b}=.008, \mathrm{p}<.10)$, supporting H4. In addition, the interaction effects of hashtag and CSR messages were positive on Likes $(\mathrm{b}=.432, \mathrm{p}<.05)$ and Shares $(\mathrm{b}=.675, \mathrm{p}<.01)$, supporting H5. However, the effects were not significant on Comments $(p>.10)$. In order to see if platform matters in the effects of CSR messages, we examined the interaction effect between platform and CSR messages and found a significant and positive effect on Shares $(b=.484, p<.05)$, which indicates that Twitter could be more effective than Facebook for CSR communications. However, the interaction effects were not significant on Likes $(p>.10)$ and Comments $(p>.10)$. Lastly, in order to explore the possibility that the zeroinflated negative binomial model outperforms the negative binomial, we conducted a Vuong test and the results suggest the negative binomial is better for the analysis (see Table 2).

\subsection{Ad-hoc Analysis}

Based on the above results, we have taken one step further to understand the types of CSR messages and examine which types of messages are more effective in social media. For this additional analysis, we considered CSR messages only and excluded non-CSR messages in the analysis. Among the CSR messages, types of CSR issues described in the messages were tagged by consumers. First, we asked the scope of beneficiary in the message and tagged it as international (3), national (2), local (1), and else (0). Therefore, messages that aim to target broader audiences have larger values. Second, we explored the role of brands in the CSR messages by their purposes and tagged as 1 if the brand is promoting a cause by another organization rather than themselves and 0 if the brand is supporting their own CSR issues. With this subset of the dataset, we estimated the negative binomial regression model using the control variables included in the main analysis.

Our main effects analysis within CSR messages shows that types of CSR issues in a message matter. We find significant negative effects of the role brand in CSR messages on Likes $(b=-.516, p<.05)$ and Shares $(b=-.434, p=<.10)$, which imply that CSR messages dealing with issues about others are less effective than the brands' own issues. We do not find a significant effect on Comments $(\mathrm{p}>.10)$. We also find a significant and negative effect of the beneficiary scope in CSR messages on Likes $(b=-.156, p<.10)$, which suggests that CSR messages that target broader scope will be less effective. However, the effects are not significant on Shares and Comments $(p>.10$, see Table 3$)$.

\section{Discussions}

This research examines the effects of CSR messages created by brands on consumer engagement in social media and explores message tone and format factors that help CSR messages become more engaging. The main effect analysis shows that firm-generated CSR messages are less engaging than non-CSR messages in social media. The effects were significant and consistent across three engagement metrics (i.e., Likes, Shares, and Comments).

Next, we explore several message tone and format factors in a message in order to find ways to improve CSR communications. For the message tone factors, we find that emotional and informational messages work in the opposite 
Table 2: Main Analysis Results

\begin{tabular}{|c|c|c|c|c|c|c|c|c|c|}
\hline \multirow{2}{*}{ Variables } & \multicolumn{3}{|c|}{ Likes } & \multicolumn{3}{|c|}{ Shares } & \multicolumn{3}{|c|}{ Comments } \\
\hline & Coeff & SE & & Coeff & SE & & Coeff & SE & \\
\hline Lag of DV & 0.000 & 0.000 & ** & 0.000 & 0.000 & $* *$ & 0.000 & 0.000 & $* *$ \\
\hline CSR message & -0.531 & 0.238 & $* *$ & -1.029 & 0.244 & $* * *$ & -0.743 & 0.414 & * \\
\hline Emotional & 0.138 & 0.094 & & 0.127 & 0.099 & & 0.115 & 0.103 & \\
\hline Informational & -0.241 & 0.089 & $* * *$ & -0.259 & 0.098 & $* * *$ & -0.020 & 0.103 & \\
\hline Humor & 0.400 & 0.112 & $* * *$ & 0.578 & 0.140 & $* * *$ & 0.021 & 0.113 & \\
\hline Length of Text & -0.002 & 0.001 & $* * *$ & -0.003 & 0.001 & $* * *$ & 0.000 & 0.001 & \\
\hline Hashtag & 0.331 & 0.080 & $* * *$ & 0.214 & 0.107 & $* *$ & 0.201 & 0.126 & \\
\hline CSR message $x$ Emotional & 0.468 & 0.243 & * & 0.521 & 0.258 & ** & 0.616 & 0.271 & ** \\
\hline CSR message $\mathrm{x}$ Informational & -0.274 & 0.233 & & -0.357 & 0.250 & & -1.065 & 0.287 & $* * *$ \\
\hline CSR message $x$ Humor & -0.202 & 0.242 & & -0.491 & 0.252 & * & 0.038 & 0.291 & \\
\hline CSR message $x$ Length of Text & 0.002 & 0.001 & * & 0.004 & 0.002 & $* * *$ & 0.008 & 0.003 & *** \\
\hline CSR message $x$ Hashtag & 0.432 & 0.220 & ** & 0.675 & 0.242 & $* * *$ & -0.233 & 0.277 & \\
\hline CSR message $x$ Platform & 0.291 & 0.223 & & 0.484 & 0.246 & ** & -0.094 & 0.272 & \\
\hline Monetary & -0.202 & 0.145 & & -0.281 & 0.153 & * & -0.084 & 0.185 & \\
\hline Picture & 0.609 & 0.110 & $* * *$ & 0.605 & 0.120 & $* * *$ & 0.079 & 0.123 & \\
\hline People & -0.056 & 0.090 & & -0.109 & 0.097 & & -0.576 & 0.114 & $* * *$ \\
\hline Product & 0.207 & 0.084 & $* *$ & 0.137 & 0.096 & & 0.180 & 0.112 & \\
\hline Video & 0.286 & 0.143 & $* *$ & 0.720 & 0.151 & $* * *$ & -0.021 & 0.170 & \\
\hline Question & -0.005 & 0.090 & & -0.027 & 0.101 & & 0.488 & 0.106 & $* * *$ \\
\hline Call to Action & -0.047 & 0.077 & & -0.208 & 0.085 & $* *$ & 0.319 & 0.108 & $* * *$ \\
\hline URL & -0.378 & 0.086 & $* * *$ & -0.373 & 0.095 & $* * *$ & -0.375 & 0.113 & $* * *$ \\
\hline Platform & -3.183 & 0.101 & $* * *$ & -0.776 & 0.132 & $* * *$ & -1.646 & 0.191 & $* * *$ \\
\hline Brand Fixed Effects & \multicolumn{3}{|c|}{$\checkmark$} & \multicolumn{3}{|c|}{$\checkmark$} & \multicolumn{3}{|c|}{$\checkmark$} \\
\hline Month & \multicolumn{3}{|c|}{$\checkmark$} & \multicolumn{3}{|c|}{$\checkmark$} & \multicolumn{3}{|c|}{$\checkmark$} \\
\hline Day of Week & \multicolumn{3}{|c|}{$\checkmark$} & \multicolumn{3}{|c|}{$\checkmark$} & \multicolumn{3}{|c|}{$\checkmark$} \\
\hline Log-Likelihood & \multicolumn{3}{|c|}{-23182.60} & \multicolumn{3}{|c|}{-18663.45} & \multicolumn{3}{|c|}{-8997.70} \\
\hline Pseudo R-Square & \multicolumn{3}{|c|}{0.0824} & \multicolumn{3}{|c|}{0.065} & \multicolumn{3}{|c|}{0.0947} \\
\hline
\end{tabular}

Note: ${ }^{* * *},{ }^{* *}$ and ${ }^{*}$ indicates significant at $1 \%, 5 \%$ and $10 \%$ level of significance based on t-statistics

directions when they are used in CSR messages. While CSR messages with emotional appeals had a positive and significant effect on all engagement metrics (i.e., Likes, Shares, and Comments), the effects of CSR messages with informational appeals had a negative effect on Comments. The findings are in line with the previous social media studies in that emotional messages are effective in general, while informative messages have mixed findings with having negative effects in some contexts. Brands can incorporate the above findings from the literature into design of CSR messages for more effective communications in social media. More specifically, social media marketing managers need to consider designing CSR messages with more emotional contents and induce arousal to generate virality. In contrast, managers may not want to design contents with informational appeals in CSR messages as it makes the effects of CSR messages on engagement more negative (i.e., less engaging). Informational appeals, especially in CSR messages, may not be a good practice according to the study findings. In line with the previous literature, informational 
Table 3: Ad-hoc Analysis Results

\begin{tabular}{|c|c|c|c|c|c|c|c|c|c|}
\hline \multirow{2}{*}{ Variables } & \multicolumn{3}{|c|}{ Likes } & \multicolumn{3}{|c|}{ Shares } & \multicolumn{3}{|c|}{ Comments } \\
\hline & Coeff & SE & & Coeff & SE & & Coeff & SE & \\
\hline Lag of DV & 0.000 & 0.000 & & 0.000 & 0.000 & $* * *$ & 0.001 & 0.001 & \\
\hline Role of Brands & -0.516 & 0.209 & $* *$ & -0.434 & 0.221 & * & -0.319 & 0.271 & \\
\hline Scope of Beneficiary & -0.156 & 0.086 & * & -0.074 & 0.094 & & -0.051 & 0.131 & \\
\hline Humor & 0.354 & 0.202 & $*$ & 0.325 & 0.228 & & 0.748 & 0.278 & $* * *$ \\
\hline Length of Text & -0.002 & 0.001 & $* *$ & -0.003 & 0.001 & $* * *$ & 0.004 & 0.002 & * \\
\hline Hashtag & 0.377 & 0.196 & * & 0.358 & 0.226 & & -0.139 & 0.280 & \\
\hline Picture & 0.949 & 0.326 & $* * *$ & 0.991 & 0.356 & $* * *$ & 0.246 & 0.408 & \\
\hline People & -0.062 & 0.182 & & -0.462 & 0.204 & ** & -0.102 & 0.256 & \\
\hline Product & -0.086 & 0.211 & & -0.281 & 0.239 & & 0.062 & 0.308 & \\
\hline Video & -0.374 & 0.274 & & 0.100 & 0.303 & & -0.855 & 0.359 & $* *$ \\
\hline Question & 0.089 & 0.178 & & 0.065 & 0.221 & & 0.966 & 0.280 & $* * *$ \\
\hline Call to Action & 0.194 & 0.170 & & 0.359 & 0.213 & * & -0.030 & 0.215 & \\
\hline URL & 0.560 & 0.204 & $* * *$ & 0.416 & 0.224 & ${ }^{*}$ & -0.069 & 0.330 & \\
\hline Platform & -3.424 & 0.234 & $* * *$ & -1.081 & 0.235 & $* * *$ & -1.941 & 0.358 & $* * *$ \\
\hline Brand Fixed Effects & \multicolumn{3}{|c|}{$\checkmark$} & \multicolumn{3}{|c|}{$\checkmark$} & \multicolumn{3}{|c|}{$\checkmark$} \\
\hline Month & \multicolumn{3}{|c|}{$\checkmark$} & \multicolumn{3}{|c|}{$\checkmark$} & \multicolumn{3}{|c|}{$\checkmark$} \\
\hline Day of Week & \multicolumn{3}{|c|}{$\checkmark$} & \multicolumn{3}{|c|}{$\checkmark$} & \multicolumn{3}{|c|}{$\checkmark$} \\
\hline Log-Likelihood & \multicolumn{3}{|c|}{$-1,932.51$} & \multicolumn{3}{|c|}{$-1,457.96$} & \multicolumn{3}{|c|}{-1126.48} \\
\hline Pseudo R-Square & \multicolumn{3}{|c|}{0.0847} & \multicolumn{3}{|c|}{0.0818} & \multicolumn{3}{|c|}{0.1476} \\
\hline
\end{tabular}

Note: ${ }^{* *},{ }^{* *}$ and ${ }^{*}$ indicates significant at $1 \%, 5 \%$ and $10 \%$ level of significance based on t-statistics

appeals in a message can lead consumers to perceive that the message is trying to be persuasive and make consumers become skeptical about the messages' true motives. As CSR messages need to authentically serve others than the firm's own purposes, consumers make judgments of a firm based on the true motives and perceived authenticity of the CSR activities. CSR messages will be even less effective if the message seems to be persuasive, as it will lead to greater skepticism about the message's authenticity or sincerity.

In addition, we explore message frame factors for effective communications of CSR messages. We have found that longer texts and a hashtag in a message help CSR messages become more engaging. While CSR messages had a negative effect on consumer engagement, the effect became positive and significant when the length of text in a message becomes longer and when a hashtag is included. Such findings are in line with the idea about perceived efforts and authenticity. Longer texts in a message provide impressions that the message was designed with great effort to achieve better quality, which in turn lead to the perception that the message was sincere or authentic. Similarly, including a hashtag in a message can provide perceptions that more effort was put in the message in order to effectively communicate with broader audience. Therefore, consumers will perceive those messages to be more authentic which will lead to higher levels of engagement.

We found partial support for the effect of humor in CSR messages to be negative on Shares only. This implies that while use of humor is generally a good practice in advertising and communications, it may not be an effective practice in CSR communications. We also found that platforms might matter in communications of CSR messages - i.e., the effect of CSR messages on Shares became positive when they were delivered on Twitter (vs. Facebook). However, we did not find significant effects of platform as a moderator of CSR and engagement on Likes and Comments. This research further analyzes the types of CSR messages by its scope of beneficiary and the role of brand in the message. The results find that broader scope of beneficiary in CSR messages have a negative effect on engagement, suggesting that closer targeting will be more effective in driving engagement. In addition, the role of brand in CSR messages had a negative 
Table 4: Summary of Results

\begin{tabular}{|l|c|c|c|}
\hline & Likes & Shares & Comments \\
\hline H1: CSR message $x$ Emotional & Supported & Supported & Supported \\
\hline H2: CSR message $x$ Informational & $x$ & $x$ & Supported \\
\hline H3: CSR message $x$ Humor & $x$ & Supported & x \\
\hline H4: CSR message $x$ Length of Text & Supported & Supported & Supported \\
\hline H5: CSR message $x$ Hashtag & Supported & Supported & $x$ \\
\hline
\end{tabular}

effect on Likes, which provides evidence that brands might need to focus on their own issues rather than introducing others' issues. The results have similar and consistent implications for effective CSR communications in social media, brands need to focus on themselves and close parties rather than trying to reach out to others or more distant parties. While we have not explored the underlying mechanism of those effects, it might be the case that focusing on the brands' own issues and close beneficiaries may deliver more clear messages and make consumers easily understand the contents. The results of the studies are summarized in Table 4.

\section{Implications and Limitations}

While social media has risen as an important communication platform for brands, marketing managers also need to use social media for effective communications for CSR activities. Therefore, this research makes the following contributions in the literature. The current social media literature has mostly focused on the effectiveness of promotional messages and this research is among the first to study how to design effective CSR messages in social media. Although recent studies demonstrate the importance of communications of CSR activities on social media and there are some studies looking at different types of topics or activities and their effectiveness, there is little evidence on effective CSR message design. As well-designed messages will be more engaging, our study explores message tone and format factors that make CSR messages more engaging in social media. This has implications for social media marketing managers. While it is important to prepare good topics for effective CSR communications, this research findings suggest that how to design messages also affects consumer engagement. Therefore, one more important step to be taken is to consider the message tone and formats after deciding topics in CSR messages.

While this research provides novel insights into the literature about effective CSR communications in social media, this research has not fully addressed the following considerations and expects future research to further develop based on the following issues.
First, while this research provides evidence on message tone and format factors that are effective in driving engagement for CSR messages using arguments based on the literature, underlying mechanisms themselves are not tested in the current research. For example, this research did not test whether longer texts and hashtags lead to higher levels of perceived efforts and authenticity. Future studies could be conducted in a laboratory and test the underlying mechanisms.

Second, this research considered Likes, Shares, and Comments in the same way to measure engagement in social media. However, we also understand that each metric has different characteristics. For example, scholars consider Shares as a measure of virality (e.g., Akpinar \& Berger, 2017) and behavioral engagement, while Likes to be a measure of attitudinal engagement and Comments to be a measure of feedback (e.g., Stephen et al., 2015). Also, there are other engagement metrics available (e.g., number of clicks) which were not utilized in this study (Stephen et al., 2015). While we did not consider the different characteristics among the metrics and potential different effects associated with each measure, future studies could benefit from exploring further and distinguishing those engagement metrics.

Third, this research did not consider time-varying effects of the study variables due to the nature of the data collection process. Future studies could benefit from collecting data by time and provide more meaningful insights on how the effects evolve over time.

Lastly, data in this research was collected several years ago and is limited several international brands and college students in Hong Kong. For generalizability, more research could be done with more recent posts and with different brands across countries.

\section{References}

Adi, A., \& Grigore, G. (2015). Communicating CSR on social media: the case of Pfizer's social media communications in Europe. In: Corporate social responsibility in the digital age (pp. 143-163); Emerald Group Publishing Limited. https://doi. org/10.1108/S2043-052320150000007009 
Akpinar, E., \& Berger, J. (2017). Valuable virality. Journal of Marketing Research, 54(2), 318-330. https://doi.org/10.1509/ jmr. 13.0350

Alhouti, S., Johnson, C. M., \& Holloway, B. B. (2016). Corporate social responsibility authenticity: Investigating its antecedents and outcomes. Journal of Business Research, 69(3), 1242-1249. https://doi.org/10.1016/j.jbusres.2015. 09.007

Ali, Q., Salman, A., Yaacob, H., Zaini, Z., \& Abdullah, R. (2020). Does Big Data Analytics Enhance Sustainability and Financial Performance? The Case of ASEAN Banks. Journal of Asian Finance, Economics, and Business, 7(7), 1-13. https://doi. org/10.13106/jafeb.2020.vol7.no7.001

Amacha, E. B., \& Dastane, O. (2017). Sustainability practices as determinants of financial performance: A Case of Malaysian Corporations. Journal of Asian Finance, Economics and Business, 4(2), 55-68. https://doi.org/10.13106/jafeb.2017. vol4.no2.55

Andrade, E. B., \& Cohen, J.B. (2007). On the consumption of negative feelings. Journal of Consumer Research, 34(3), 283300. https://doi.org/10.1086/519498

Bagozzi, R. P., Gopinath, M., \& Nyer, P.U. (1999). The role of emotions in marketing. Journal of the Academy of Marketing Science, 27(2), 184-206. https://doi.org/10.1177/ 0092070399272005

Berger, J. (2011). Arousal increases social transmission of information. Psychological Science, 22(7), 891-893. https:// doi.org/10.1177/0956797611413294

Berger, J., \& Milkman, K. L. (2012). What makes online content viral?. Journal of Marketing Research, 49(2), 192-205. https:// doi.org/10.1509/jmr.10.0353

Berger, J., \& Schwartz, E. M. (2011). What drives immediate and ongoing word of mouth?. Journal of Marketing Research, 48(5), 869-880. https://doi.org/10.1509/jmkr.48.5.869

Beverland, M. (2006). The 'real thing': Branding authenticity in the luxury wine trade. Journal of Business Research, 59(2), 251258. https://doi.org/10.1016/j.jbusres.2005.04.007

Brown, T. J., \& Dacin, P. A. (1997). The company and the product: Corporate associations and consumer product responses. Journal of Marketing, 61(1), 68-84. https://doi.org/10.1177/ 002224299706100106

Bryant, J., Alan, D. B., Silberberg, R., \& Elliott, S. M. (1981). Effects of humorous illustrations in college textbooks. Human Communication Research, 8(1), 43-57. https://doi. org/10.1111/j.1468-2958.1981.tb00655.x

Chandy, R. K., Tellis, G. J., MacInnis, D. J., \& Thaivanich, P. (2001). What to say when: Advertising appeals in evolving markets. Journal of Marketing Research, 38(4), 399-414. https://doi.org/10.1509/jmkr.38.4.399.18908

Cone Communications. (2017). 2017 Cone Communications CSR study. Boston, MA, USA. Retrieved August 7, 2020, from https:/www.conecomm.com/2017-cone-communications-csrstudy-pdf.

De Angelis, M., Bonezzi, A., Peluso, A. M., Rucker, D. D., \& Costabile, M. (2012). On braggarts and gossips: A selfenhancement account of word-of-mouth generation and transmission. Journal of Marketing Research, 49(4), 551-563. https://doi.org/10.1509/jmr.11.0136

De Vries, L., Gensler, S., \& Leeflang, P. S. (2012). Popularity of brand posts on brand fan pages: An investigation of the effects of social media marketing. Journal of Interactive Marketing, 26(2), 83-91. https://doi.org/10.1016/j.intmar.2012.01.003

Du, S., Bhattacharya, C. B., \& Sen, S. (2007). Reaping relational rewards from corporate social responsibility: The role of competitive positioning. International Journal of Research in Marketing, 24(3), 224-241. https://doi.org/10.1016/j. ijresmar.2007.01.001

Eisend, M. (2009). A meta-analysis of humor in advertising. Journal of the Academy of Marketing Science, 37(2), 191-203. https:// doi.org/10.1007/s11747-008-0096-y

Ellen, P. S., Webb, D. J., \& Mohr, L. A. (2006). Building corporate associations: Consumer attributions for corporate socially responsible programs. Journal of the Academy of Marketing Science, 34(2), 147-157. https://doi. org/10.1177/0092070305284976

Freedman, M., \& Jaggi, B. (1982). Pollution disclosures, pollution performance and economic performance. Omega, 10(2), 167176. https://doi.org/10.1016/0305-0483(82)90051-2

Gilmore, J. H., \& Pine, B. J. (2007). Authenticity: What consumers really want. Boston, MA: Harvard Business School Press.

Goldberg, M. E., \& Gorn, G. J. (1987). Happy and sad TV programs: How they affect reactions to commercials. Journal of Consumer Research, 14(3), 387-403. https://doi.org/10.1086/209122

Heath, C., Bell, C., \& Sternberg, E. (2001). Emotional selection in memes: the case of urban legends. Journal of Personality and Social Psychology, 81(6), 1028-1041. https://doi. org/10.1037/0022-3514.81.6.1028

Lee, D., Hosanagar, K., \& Nair, H. S. (2018). Advertising content and consumer engagement on social media: evidence from Facebook. Management Science, 64(11), 5105-5131. https:// doi.org/10.1287/mnsc.2017.2902

MacInnis, D. J., Rao, A. G., \& Weiss, A. M. (2002). Assessing when increased media weight of real-world advertisements helps sales. Journal of Marketing Research, 39(4), 391-407. https://doi.org/10.1509/jmkr.39.4.391.19118

Madden, T. J., \& Weinberger, M. G. (1984). Humor in advertising: A practitioner view. Journal of Advertising Research, 24(4), 23-29.

Mohr, L.A., Webb, D. J., \& Harris, K. E. (2001). Do consumers expect companies to be socially responsible? The impact of corporate social responsibility on buying behavior. Journal of Consumer Affairs, 35(1), 45-72. https://doi.org/10.1111/j.1745-6606.2001. tb00102.x 
Moldovan, S., Goldenberg, J., \& Chattopadhyay, A. (2011). The different roles of product originality and usefulness in generating word-of-mouth. International Journal of Research in Marketing, 28(2), 109-119. https://doi.org/10.1016/j. ijresmar.2010.11.003

Muntinga, D. G., Moorman, M., \& Smit, E. G. (2011). Introducing COBRAs: Exploring motivations for brand-related social media use. International Journal of Advertising, 30(1), 13-46. https://doi.org/10.2501/IJA-30-1-013-046

Napoli, J., Dickinson, S. J., Beverland, M. B., \& Farrelly, F. (2014). Measuring consumer-based brand authenticity. Journal of Business Research, 67(6), 1090-1098. https://doi.org/10.1016/j. jbusres.2013.06.001

Park, Y. E. (2019). Data empowered insights for sustainability of Korean MNEs. Journal of Asian Finance, Economics and Business, 6(3), 173-183. https://doi.org/10.13106/jafeb.2019. vol6.no3.173

Pava, M. L., \& Krausz, J. (1996). The association between corporate social-responsibility and financial performance: The paradox of social cost. Journal of Business Ethics, 15(3), 321-357.

Rietveld, R., van Dolen, W., Mazloom, M., \& Worring, M. (2020). What you feel, is what you like influence of message appeals on customer engagement on Instagram. Journal of Interactive Marketing, 49, 20-53. https://doi.org/10.1016/j. intmar.2019.06.003Get

Rimé, B. (2009). Emotion elicits the social sharing of emotion: Theory and empirical review. Emotion Review, 1(1), 60-85. https://doi.org/10.1177/1754073908097189

Saxton, G. D., Gómez, L., Ngoh, Z., Lin, Y. P., \& Dietrich, S. (2019). Do CSR messages resonate? Examining public reactions to firms' CSR efforts on social media. Journal of Business Ethics, 155(2), 359-377. https://doi.org/10.1007/ s10551-017-3464-Z

Saxton, G. D., Niyirora, J., Guo, C., \& Waters, R. (2015). \# AdvocatingForChange: The strategic use of hashtags in social media advocacy. Advances in Social Work, 16(1), 154-169.

Skarmeas, D., \& Leonidou, C.N. (2013). When consumers doubt, watch out! The role of CSR skepticism. Journal of Business Research, 66(10), 1831-1838. https://doi.org/10.1016/j. jbusres.2013.02.004

Speck, P. S. (1987). On humor and humor in advertising. Doctoral dissertation. Lubbock, TX: Texas Tech University.
Sreejesh, S., Sarkar, J. G., \& Sarkar, A. (2019). CSR through social media: examining the intervening factors. Marketing Intelligence \& Planning, 38(1), 103-120. https://doi. org/10.1108/MIP-12-2018-0569

Stephen, A. T., Sciandra, M. R., \& Inman, J. J. (2015). The effects of content characteristics on consumer engagement with branded social media content on Facebook. Working Paper Series No. 15-110, Cambridge, MA: Marketing Science Institute. Available at: https://www.msi.org/wp-content/uploads/2020/06/MSI Report_15-1101.pdf

Sternthal, B., \& Craig, C.S. (1973). Humor in advertising. Journal of Marketing, 37(4), 12-18. https://doi. org/10.1177/002224297303700403

Verlegh, P. W., Verkerk, C., Tuk, M. A., \& Smidts, A. (2004). Customers or sellers? The role of persuasion knowledge in customer referral. In: B. E. Kahn, \& M. F. Luce (Eds.), Advances in Consumer Research, Volume 31 (pp. 304-305), Valdosta, GA: Association for Consumer Research.

Wang, R., \& Huang, Y. (2018). Communicating corporate social responsibility (CSR) on social media. Corporate Communications: An International Journal, 23(3), 326-341. https://doi.org/10.1108/CCIJ-07-2017-0067

Weinberger, M. G., \& Campbell, L. (1991). The use and impact of humor in radio advertising. Journal of Advertising Research, 31(1), 644-652.

Weinberger, M. G., \& Gulas, C. S. (1992). The impact of humor in advertising: A review. Journal of Advertising, 21(4), 35-59. https://doi.org/10.1080/00913367.1992.10673384

Woltman Elpers, J. L., Mukherjee, A., \& Hoyer, W. D. (2004). Humor in television advertising: A moment-to-moment analysis. Journal of Consumer Research, 31(3), 592-598. https://doi.org/10.1086/425094

Yang, M., Ren, Y., \& Adomavicius, G. (2019). Understanding user-generated content and customer engagement on Facebook business pages. Information Systems Research, 30(3), 839-855. https://doi.org/10.1287/isre.2019.0834

Yoo, C., \& MacInnis, D. (2005). The brand attitude formation process of emotional and informational ads. Journal of Business Research, 58(10), 1397-1406. https://doi.org/10.1016/j. jbusres.2005.03.011 